\title{
10. The Australia-Papua New Guinea Torres Strait Treaty: a model for co-operative management of the South China Sea?
}

\section{Ben Milligan}

\section{INTRODUCTION}

On 18 December 1978 Australia and Papua New Guinea (PNG) concluded a treaty concerning maritime delimitation and co-operative arrangements in the Torres Strait ${ }^{1}$ (Torres Strait Treaty). The Torres Strait Treaty also addressed competing positions asserted by Australia and PNG concerning sovereignty over the Strait's insular features. This chapter provides a brief overview of the Torres Strait Treaty and its implementation by Australia and PNG. It then discusses the extent to which design features of the Treaty could be utilised as a model for co-operative management of the South China Sea.

\section{POLITICAL AND PHYSICAL GEOGRAPHY OF THE TORRES STRAIT ${ }^{2}$}

The Torres Strait is an area of water located between Cape York Peninsula in northern Australia and the island of New Guinea. The Strait connects

1 Treaty between Australia and the Independent State of Papua New Guinea Concerning Sovereignty and Maritime Boundaries in the Area between the Two countries, Including the Area Known as Torres Strait, and Related Matters, signed 18 December 1978, entered into force 15 February 1985, 18 ILM 291; ATS 1985 No 4.

2 For further discussions see S Kaye, The Torres Strait (The Hague: Kluwer Law International, 1997); D Lawrence and T Cansfield-Smith (eds) Sustainable Development for Traditional Inhabitants of the Torres Strait Region (Canberra: Australian Government Publishing Service, 1991); D Lawrence and HR Lawrence, 
the Coral Sea in the east with the Arafura Sea to the west. It extends approximately 150 kilometres from north to south and 200 kilometres from east to west. The Strait is relatively shallow and contains more than 150 insular features, including islands, sand cays and drying reefs. ${ }^{3}$ Approximately 17 of these islands are inhabited by the culturally and linguistically distinct 'Torres Strait Islander' people, many of whom maintain their traditional lifestyle. ${ }^{4}$ The Torres Strait region is sparsely populated and is isolated from major population centres and infrastructure in Australia and PNG. ${ }^{5}$

\section{A. Natural Resources}

The natural environment of the Torres Strait is subject to a tropical climate and has a high degree of biodiversity. ${ }^{6}$ The Strait provides habitats for several vulnerable or endangered species, notably dugongs and several species of turtle. ${ }^{7}$ It has been recognised by a United Nations Environment Programme report as 'the most important dugong habitat in the world'. ${ }^{8}$ The Strait also supports small commercial fisheries for several stocks including prawns, mackerel and rock lobster. ${ }^{9}$ Although the economic activity based in the Torres Strait is of minor significance to the surrounding States, the Torres Strait people rely greatly on the region's marine living resources for their livelihoods and for food. ${ }^{10}$ As discussed

'The Torres Strait: the region and its people' in R Davis, Woven Histories Dancing Lives: Torres Strait Islander Identify, Culture and History (2004), online: http:// 1ryb.aiatsis.gov.au/PDFs/davis_pt1.pdf; and Australian Senate, Foreign Affairs, Defence and Trade References Committee, The Torres Strait: Bridge and Border (November 2010), online: http://www.aph.gov.au/senate/committee/?url=fadt_ctte/ completed_inquiries/2010-13/torresstrait/index.htm.

3 Kaye, supra note 2, at 5-9.

4 Lawrence and Lawrence, supra note 2.

5 Kaye, supra note 2, at 12-13.

6 Australian Department of Sustainability, Environment, Water, Population and Communities, Biodiversity, Summary for the NRM Region Torres Strait, Queensland, online: http://www.environment.gov.au/heritage/anhat/summaries/ qld/pubs/summary-qld-torres-strait.pdf.

7 See Australian Senate Committee Report, supra note 2, Chapter 9.

8 United Nations Environment Programme, Dugong Status Report and Action Plans for Countries and Territories (2002), UNEP/DEWA/RS.02-1, online: http:// www.unep.org/NairobiConvention/docs/dugong.pdf.

9 Australian Maritime Safety Authority (AMSA) Document. Note also that there is traditional fishing for Dugong and Green Turtle.

10 Australian Maritime Safety Authority, Torres Strait:'Strait Facts'/Risk Assessment, online: http://www.amsa.gov.au/marine_environment_protection/ 
in further detail below, Australia and PNG have established a moratorium concerning certain exploration and exploitation of the region's potential hydrocarbon resources.

\section{B. Shipping and Navigation}

The Torres Strait is also an important shipping route. ${ }^{11}$ For example, it provides the shortest available route for vessels travelling from Southeast Asia to New Zealand, PNG, the South Pacific and the major population centres of the Australian east coast. ${ }^{12}$ Navigation through the Torres Strait is complicated by several factors. Muddy waters in several locations obscure reefs and shifting sandbanks. ${ }^{13}$ The Strait experiences tropical storms and heavy rain that greatly reduce visibility. ${ }^{14}$ It is extremely difficult to predict tides in several locations. ${ }^{15}$ Tidal patterns vary widely in different parts of the Strait and several locations experience strong tidal streams. ${ }^{16}$ The navigable route through the Torres Strait is highly confined in both width and depth. ${ }^{17}$ Very-large vessels do not use the Strait - the recommended maximum draft for transiting ships is currently 12.2 metres with an under-keel clearance of 10 per cent. ${ }^{18}$ Navigation through the

torres_strait/risk.asp. Prior to their decline in the 1960s, the pearling and pearl shell fishing industries were important contributors to the regional economy; see Kaye, supra note 2, at 39-40, 48.

11 Australian Maritime Safety Authority, ibid, notes the following: There are approximately 3000 transits of the Strait per year by vessels with LOA greater than 50 metres. The approximate breakdown of vessel traffic is as follows: bulk carriers $(38 \%)$, general cargo $(28 \%)$, containers $(15 \%)$, loaded tankers $(12 \%)$. See also Kaye, supra note 2 , at $14-16$.

12 Kaye, supra note 2, at 14.

13 Kaye, supra note 2, at 2.

14 Australian Maritime Safety Authority, supra note 10.

15 Kaye, supra note 2, at 4, who notes the following: Large ships require real time telemetry on tidal levels. Tidal data is broadcasted from several monitoring stations maintained by the Australian Government.

16 Ibid. See also R Johannes and J Macfarlane, Traditional Fishing in the Torres Strait Islands (Collingwood, Victoria: CSIRO Publishing, 1991), at 16-18; and E Wolanski, 'A Review of the Physical Oceanography of the Torres Strait' in Lawrence and Cansfield-Smith, supra note 2, at 135-7.

17 Australian Maritime Safety Authority, supra note 10, which notes the following: 'The western entry to the Torres Strait through Varzin Channel has a minimum width of $0.3 \mathrm{~nm}$ and depth of 10.5 metres. Prince of Wales Channel, the passage route in the central Torres Strait, has a minimum width of $0.3 \mathrm{~nm}$ and depth of 11.0 metres.'

18 See Australian Maritime Safety Authority, Under Keel Clearance Management: Management of under-keel clearance for ships transiting Torres Strait, 
Strait is currently subject to a compulsory pilotage scheme administered by the Australian Government. ${ }^{19}$

\section{COMPETING CLAIMS AND NEGOTIATION OF THE TORRES STRAIT TREATY ${ }^{20}$}

\section{A. Historical Background}

In 1879, in response to concerted lobbying efforts by the colony of Queensland, the United Kingdom permitted the colony to annex islands located in the Torres Strait. ${ }^{21}$ The United Kingdom subsequently proclaimed a separate protectorate over the south-eastern portion of $\mathrm{New}$ Guinea in $1884 .^{22}$ These acts brought the territory in and surrounding the Torres Strait under British control. The potential for competing jurisdictional claims arose in the Torres Strait in 1975 when the Territory of Papua New Guinea achieved independence from Australian administration. ${ }^{23}$ The Australian government and Papua New Guinea territorial government commenced negotiations concerning maritime boundary delimitation in $1973 .^{24}$ A mutually acceptable agreement was not reached prior to PNG's independence and the negotiations continued until 1978. ${ }^{25}$ Several factors delayed the final agreement set out in the Torres Strait Treaty, which will be discussed in the following paragraphs.

online: http://www.amsa.gov.au/shipping_safety/great_barrier_reef_and_torres_ strait/under_keel_clearance_management.asp.

19 For further discussion of the scheme and associated international legal issues see: $\mathrm{S}$ Bateman and $\mathrm{M}$ White, 'Compulsory Pilotage in the Torres Strait: Overcoming Unacceptable Risks to a Sensitive Marine Environment', (2009) 40 Ocean Dev \& Int'l L 184; R Beckman, 'PSSAs and Transit Passage - Australia's Pilotage System in the Torres Strait Challenges the IMO and UNCLOS', (2007) 38 Ocean Dev \& Int'l L 325.

20 For further discussion, see Kaye, supra note 2; H Burmester, 'The Torres Strait Treaty: Ocean Boundary Delimitation by Agreement', (1982) 76 AJIL 321; P Boyce and M White (eds), The Torres Strait Treaty (Canberra: ANU Press, 1981).

21 Kaye, supra note 2, at 36-8 and Burmester, supra note 20.

22 Ibid.

23 Kaye, supra note 2, at 90-1.

24 Kaye, supra note 2, at 90-1 and Burmester, supra note 20.

25 Ibid. 


\section{B. Sovereignty over Insular Features and Access to the Torres Strait's Resources}

Under authorisation of the United Kingdom, most Torres Strait islands were annexed to the colony of Queensland in the 1870 s, and subsequently became Australian territory. Australian sovereignty over insular features in the Torres Strait severely limited the potential scope of PNG's maritime jurisdiction and its access to the Strait's resources. The islands of Boigu and Saibai, for example, are located less than 10 kilometres from the PNG coast. ${ }^{26}$ PNG considered this situation to be inequitable, particularly in light of its status as a newly independent developing State. ${ }^{27}$ During the negotiations it attempted to secure sovereignty over insular features in the northern part of the Strait and greater access to the Strait's resources. ${ }^{28}$

\section{Domestic Legal and Political Issues in Australia}

The Queensland state government remained strongly opposed to any transfer of territory to PNG. ${ }^{29}$ The Australian Constitution restricts the ability of the Australian federal government to override such opposition and, in any event, the co-operation of the Queensland state government was deemed to be essential for the successful implementation of an agreement with PNG. ${ }^{30}$

\section{Welfare of Torres Strait Islanders}

Many Torres Strait Islanders were opposed to any reallocation of sovereignty to PNG. It was perceived that the Australian Government could provide better protection of the Islanders' economic security and distinct cultural identity. ${ }^{31}$

26 For an illustrative map of several Torres Strait islands, see Figure 10.1. A detailed map can be found online: http://www.icsm.gov.au/mapping/images/torres. pdf.

27 Kaye, supra note 2, at 90-2.

28 Ibid.

29 Ibid.

30 Kaye, supra note 2, at 92 notes that: 'While there was some academic debate over the appropriate legal procedures by which islands could be transferred to PNG, it was clear that nothing could be ceded without at least the approval of the QLD Parliament and possible not without a referendum in the State.' For further discussion concerning Australian constitutional law see R Lumb, 'Legal aspects of the Torres Strait Treaty' in Boyce and White, supra note 20.

31 Kaye, supra note 2, at 90-2. 
The agreement reflected in the Torres Strait Treaty reconciled the divergent interests of Australia and PNG by establishing both maritime boundaries and several complementary co-operative mechanisms concerning management of the Torres Strait and its resources. The Treaty is a complex legal instrument, containing 32 articles and nine annexes. Key design features of the Treaty are discussed in the following paragraphs.

\section{DESIGN FEATURES OF THE TORRES STRAIT TREATY ${ }^{32}$}

\section{A. Objectives of the Treaty}

The preamble of the Torres Strait Treaty emphasises several key policy objectives, namely: establishment of an agreed position concerning maritime boundary delimitation and sovereignty over certain Torres Strait islands; protection of the traditional way of life and livelihood of Australian Torres Strait Islanders and Papua New Guineans living in and adjacent to the Strait; protection of the Strait's marine environment; freedom of navigation and over flight in the Torres Strait area for Australian and Papua New Guinean vessels and aircraft; and co-operative management and sharing of the Strait's fisheries and seabed mineral resources.

\section{B. Delimitation of Maritime Boundaries}

The Torres Strait Treaty establishes several maritime jurisdictional boundaries between Australia and PNG. A 'Seabed Jurisdiction Line' delimits the sovereign rights of each State over the continental shelf. ${ }^{33}$ The Treaty explicitly recognises that these rights include 'jurisdiction over low-tide elevations, and the right to exercise such jurisdiction in respect of those elevations, in accordance with international law'. ${ }^{34}$ A 'Fisheries Jurisdiction Line' delimits the sovereign rights of each State 'for the purpose of exploring and exploiting, conserving and managing fisheries resources other

32 For further discussion see Kaye, supra note 2, Burmester, supra note 20, and $\mathrm{J}$ Charney and L Alexander, International Maritime Boundaries of the World (Dordrecht/Boston: Martinus Nijhoff Publishers, 1993), at 929-75.

33 Torres Strait Treaty, Art 4(1). The coordinates of the line are set out in Annex 5 of the Treaty.

34 Torres Strait Treaty, Art 1(1)(i). 
than sedentary species'. ${ }^{35}$ Territorial sea boundaries are also established between the mainland coast of PNG and several islands which, as noted below, are recognised by the Treaty as belonging to Australia. ${ }^{36}$

In the eastern and western approaches to the Torres Strait the Seabed Jurisdiction Line and Fisheries Jurisdiction Line follow the same course, which apart from minor adjustments is equidistant from the mainland coasts of Australia and PNG ${ }^{37}$ In the central part of the Torres Strait each line follows a different course. The Seabed Jurisdiction Line runs north of an equidistance line between the mainland coasts, taking into account Australian sovereignty over certain Torres Strait Islands. ${ }^{38}$ The Fisheries Jurisdiction Line turns sharply northward from the Seabed Jurisdiction Line to enclose several inhabited islands. The course of the Seabed Jurisdiction Line and Fisheries Jurisdiction Line in the central portion of the Strait is depicted in Figure 10.1.

The Torres Strait Treaty also refers to the 'residual jurisdiction' of Australia and PNG, which covers several matters including preservation of the marine environment, marine scientific research, and the production of energy from water currents and winds. ${ }^{39}$ In non-territorial sea waters located between the Seabed Jurisdiction Line and Fisheries Jurisdiction Line, Australia and PNG may not exercise residual jurisdiction unless the other State consents. ${ }^{40} \mathrm{Within}$ these waters both States are also required to 'consult with a view to reaching agreement on the most effective method of application of measures involving the exercise of residual jurisdiction' ${ }^{4}$ The Treaty does not contain provisions concerning the exercise of residual

35 Torres Strait Treaty, Arts 4(2) and 1(1)(b). The coordinates of the line are set out in Annex 8 of the Treaty.

36 Torres Strait Treaty, Art 3(1).

37 For further discussion see Kaye, supra note 2, at 93-9; Charney and Alexander, supra note 32.

38 Ibid.

39 Torres Strait Treaty, Art 4(4) stipulates that the term 'Residual Jurisdiction' means: '(a) jurisdiction over the area other than seabed jurisdiction of fisheries jurisdiction, including jurisdiction other than seabed jurisdiction of fisheries jurisdiction insofar as it relates to inter alia: (i) the preservation of the marine environment; (ii) marine scientific research; and (iii) the production of energy from water, current and winds; and (b) seabed jurisdiction and fisheries jurisdiction to the extent that the exercise of such jurisdiction is not directly related to the exploration or exploitation of resources or to the prohibition of, or refusal to authorise, activities subject to that jurisdiction.' Burmester AJIL notes that 'Essentially ... any exercise of jurisdiction not directly related to the control of seabed or fisheries resources falls within the definition of residual jurisdiction.'

40 Torres Strait Treaty, Art 4(3).

41 Ibid. 
jurisdiction outside the area bounded by the Seabed Jurisdiction Line and Fisheries Jurisdiction Line. ${ }^{42}$ In practice, the segments of these lines that follow a common course have been treated as an all-purpose maritime boundary by both Australia and PNG.

\section{Allocation of Sovereignty}

In the interest of clarity, the concept of 'sovereignty over an island' is expressly defined by the Torres Strait Treaty to include the territorial sea, insular features located within the territorial sea, underlying seabed and subsoil, and superjacent airspace. ${ }^{43}$ Article 2(1) of the Treaty recognises Australian sovereignty over all islands located south of the Seabed Jurisdiction Line and 15 specified islands located northward. ${ }^{44}$ Some of these 15 specified Australian islands are located north of both the Seabed Jurisdiction Line and the Fisheries Jurisdiction Line. Article 2(3) of the Treaty recognises the sovereignty of PNG over three small islands located immediately adjacent to the coast of New Guinea and over all islands located north of the Seabed Jurisdiction Line (except for the 15 allocated to Australia).

Article 3 of the Torres Strait Treaty contains several provisions concerning territorial sea limits in the Torres Strait. The limit of the territorial sea projected from the 15 Australian islands located north of the Seabed Jurisdiction Line is fixed at three miles, notwithstanding any subsequent change to the configuration of the relevant coastlines..$^{45}$ This restriction does not apply to an area of territorial sea located south of the Seabed Jurisdiction Line but projected from Pearce Caye - an island located less than three miles north of the Seabed Jurisdiction Line. ${ }^{46}$ Australia is prohibited from extending its territorial sea northwards across the Seabed

\footnotetext{
42 For further discussion, see Burmester, supra note 20.

43 Torres Strait Treaty, Art 2(4).

44 Torres Strait Treaty, Art 2(2) provides that 'No island over which Australia has sovereignty, other than those specified' is located north of the Seabed Jurisdiction Line.

45 Torres Strait Treaty, Art 3(2), which also provides that the three mile restriction applies even if there is a different result of a subsequent geographic survey. The fixed territorial sea limits are defined in Annex 3 of the Treaty and illustrated in Annexes 2 and 4. Kaye, supra note 2; This was done with an extraordinary degree of detail and is best illustrated in the case of Turnagain Island, which, although less than several miles long and a mile wide, has some 74 basepoints for the calculation of its territorial sea

46 Torres Strait Treaty, Art 3(3).
} 
Jurisdiction Line. ${ }^{47}$ PNG is prohibited from (1) extending certain parts of its mainland territorial sea beyond three miles; (2) extending its archipelagic waters or territorial sea into the waters located between the Seabed Jurisdiction Line and Fisheries Jurisdiction Line; (3) designating archipelagic baselines in those same waters; and (4) extending its territorial sea southwards of the Seabed Jurisdiction Line.

\section{A Complex Patchwork of Adjacent Maritime Jurisdiction}

The practical effect of the above provisions is as follows: The Torres Strait Treaty recognises Australian sovereignty over the large majority of islands located in the Strait. ${ }^{48}$ Waters located north of both the Seabed Jurisdiction Line and Fisheries Jurisdiction Line are subject to the jurisdiction of PNG, but also contain pockets of Australian territorial sea surrounding certain islands. Waters located north of the Seabed Jurisdiction Line and south of the Fisheries Jurisdiction Line are subject to the seabed jurisdiction of PNG, the fisheries jurisdiction of Australia, and contain pockets of Australian territorial sea surrounding certain islands. Each State is only entitled to exercise residual jurisdiction in these waters if the other State provides consent. Waters located south of both the Seabed Jurisdiction Line and Fisheries Jurisdiction Line are subject to Australian jurisdiction.

\section{E. Zonal Joint Management of the Torres Strait}

Article 10 of the Torres Strait Treaty establishes 'A Protected Zone in the Torres Strait' (Protected Zone) that comprises 'all the land, sea, airspace, seabed and subsoil' enclosed by a line described in Annex 9 of the Treaty. ${ }^{49}$ The Protected Zone straddles the Seabed Jurisdiction Line and surrounds all Australian islands in the Torres Strait except for those located close to the Cape York Peninsula. It also incorporates several islands allocated by the Treaty to PNG. The approximate extent of the Protected Zone is depicted in Figure 10.1.

The Protected Zone has two stated purposes. Article 10(3) of the Torres Strait Treaty provides that the "principal purpose of the Parties in establishing the Protected Zone, and in determining its ... boundaries, is to

\footnotetext{
47 Torres Strait Treaty, Art 3(4).

48 Torres Strait Treaty, Art 2(1).

49 For coordinates and illustrative maps of the Protected Zone, see Torres Strait Treaty, Annexes 2, 6, 7, and 9.
} 


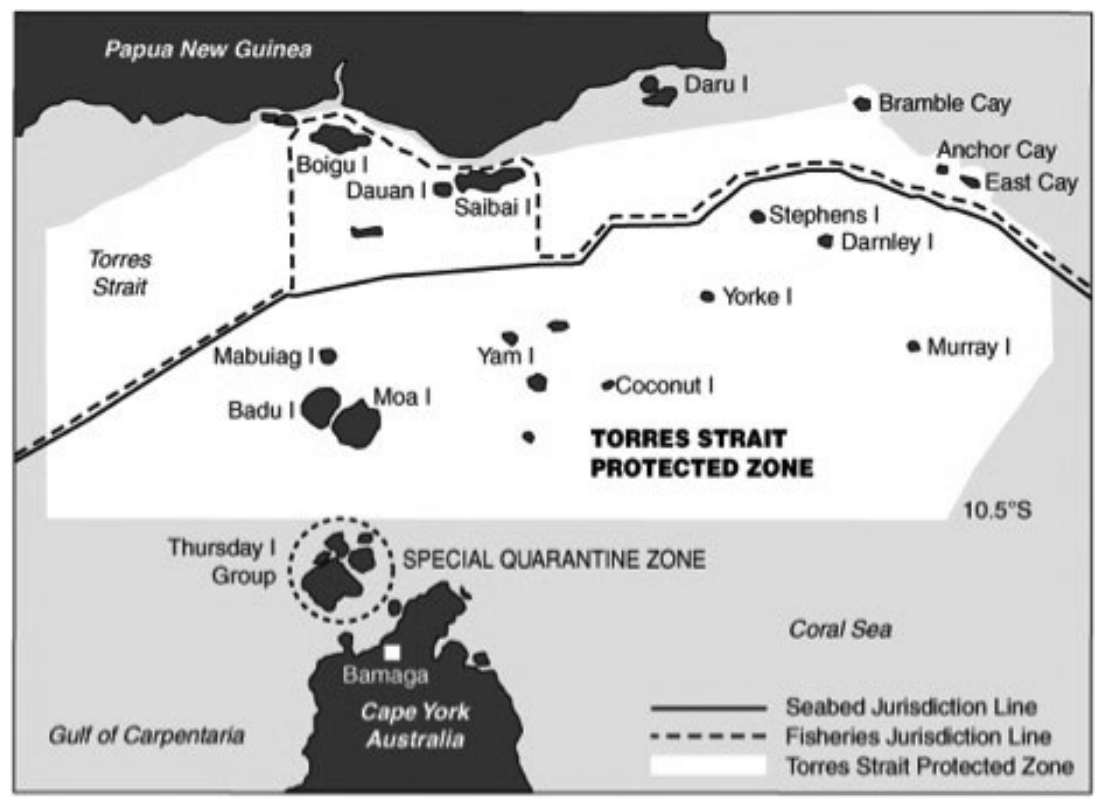

Figure 10.1 The Torres Strait Treaty: boundary delimitation and protected zone ${ }^{50}$

acknowledge and protect the traditional way of life and livelihood of the traditional inhabitants including their traditional fishing and free movement'. Article 10(4) of the Treaty provides that a 'further purpose of the Parties in establishing the Protected Zone is to protect and preserve the marine environment and indigenous fauna and flora in and in the vicinity of the Protected Zone'.

\section{F. Cooperative Management of the Protected Zone}

The Torres Strait Treaty contains complex provisions concerning the co-operative management of the Protected Zone and its resources by Australia and PNG. These provisions are addressed comprehensively in other literature ${ }^{51}$ and will not be addressed in detail by this chapter. It

50 This image is a derivate work of a map published on the Australian Department of Foreign Affairs website. Both the original and derivate works are subject to a Creative Commons Attribution 3.0 Australia licence.

51 See for example, supra note 20. 
is, however, relevant to note that within the Protected Zone, the Treaty provides several protections concerning the life and livelihood of traditional inhabitants of the Torres Strait. Australia and PNG are obliged to continue to permit free movement and the performance of lawful traditional activities (including traditional fishing) in and in the vicinity of the Protected Zone. ${ }^{52}$ Certain traditional customary rights preserved by one State shall be extended to nationals of the other State on no less favourable terms. ${ }^{53}$ Provided they are engaged in traditional activities, visitors to the Zone from either State are not subject to government controls concerning immigration, customs, quarantine or health. ${ }^{54}$

The Treaty also contains several mechanisms concerning environmental and wildlife protection in and in the vicinity of the Protected Zone. Australia and PNG are required to take legislative and other measures concerning the protection and preservation of the marine environment, including measures to prevent and control various sources of marine pollution. ${ }^{55}$ In formulating these measures, each State is required 'take into account internationally agreed rules, standards and recommended practices which have been adopted by diplomatic conferences or by relevant international organisations' ${ }^{56}$ Both States are also required to consult and communicate with one another concerning (1) the environmental impact of planned activities and (2) the harmonisation and implementation of environmental protection and preservation measures. ${ }^{57}$ Each State is obliged to use its best endeavours to control noxious species and identify and protect threatened indigenous fauna and flora. ${ }^{58}$

Articles 18 and 19 of the Torres Strait Treaty establish co-operative mechanisms concerning joint administration of the Protected Zone and implementation of the Treaty's provisions, including at a local level. Australia and PNG are required to designate one 'representative' each. ${ }^{59}$ The two representatives are required to perform a wide variety of consultative and monitoring functions, particularly concerning the practical and local operation of the Treaty and the resolution of problems associ-

\footnotetext{
52 Torres Strait Treaty, Art 11.

53 Torres Strait Treaty, Art 12.

54 Torres Strait Treaty, Art 16, which also reserves the right for each party to apply such measures in certain circumstances, including: to control abuses involving illegal entry or evasion of justice; and to address the outbreak or spread of disease or pests.

55 Torres Strait Treaty, Art 13(1) and (2).

56 Torres Strait Treaty, Art 13(1).

57 Torres Strait Treaty, Art 13(4)-(6).

58 Torres Strait Treaty, Art 14.

59 Torres Strait Treaty, Art 18(1).
} 
ated with its implementation. ${ }^{60}$ Each representative is based at a specified location in the Torres Strait region, unless circumstances require otherwise. ${ }^{61}$ Both States are also required to establish and maintain a 'Torres Strait Joint Advisory Council' (Advisory Council) ${ }^{62}$ comprised initially of at least two national representatives; at least one member from each of the relevant sub-national governments (the Government of Queensland from Australia and the Fly River Provincial Government from PNG); and at least three members representing the traditional inhabitants. ${ }^{63}$ The functions of the Advisory Council are to review and discuss certain matters associated with implementation of the Treaty and to seek solutions to implementation problems. ${ }^{64}$

\section{G. Seabed Mining and Drilling}

Article 6 of the Torres Strait Treaty requires Australia and PNG to consult with a view to reaching agreement concerning the joint development of certain potential hydrocarbon deposits straddling the seabed boundary between both States ${ }^{65}$ Article 15 of the Torres Strait Treaty prohibits each party from undertaking or permitting seabed mining and drilling within the Protected Zone for a period of ten years following the Treaty's entry into force. As noted below, the moratorium on seabed mining and drilling in the Protected Zone has been extended on several occasions, most recently on an indefinite basis.

\section{H. Joint Management of Marine Living Resources in the Protected Zone}

The Torres Strait Treaty establishes a detailed co-operative framework concerning commercial fisheries in the Protected Zone. An important function of these provisions is to enable PNG to access a greater share of the Strait's marine living resources than its maritime zones would otherwise permit. ${ }^{66}$ Article 20 of the Treaty affords priority to traditional fishing

\footnotetext{
60 Torres Strait Treaty, Art 18(2)-(3).

61 Torres Strait Treaty, Art 18(4).

62 Torres Strait Treaty, Art 19(1).

63 Torres Strait Treaty, Art 19(6).

64 Torres Strait Treaty, Art 19(2). Note that the Advisory Council is specifically prohibited from assuming management or administration responsibilities, which the Treaty provides shall 'continue to lie with the relevant national, State, Provincial and local authorities': Art 19(3).

65 Note also Torres Strait Treaty, Art 5, concerning existing petroleum permits.

66 Kaye, supra note 2, at 103.
} 
activities - provisions of the Treaty concerning commercial fisheries in the Protected Zone shall not prejudice traditional fishing, and both States are required to use best endeavours to minimise the impact of fisheries conservation measures on such activities. Articles 21-28 of the Treaty contain complex provisions concerning, inter alia: joint determination of a total allowable catch; allocation of this catch between Australia and PNG; negotiation of subsidiary conservation and management measures for individual fisheries; transitional measures; licensing arrangements; management of fishing within the Protected Zone by third States; and inspection and enforcement.

\section{Other Cooperative Mechanisms}

In addition to the various requirements discussed above, the Torres Strait Treaty obliges Australia and PNG to co-operate concerning the provision and maintenance navigational aids, ${ }^{67}$ and the exercise of jurisdiction over certain shipwrecks. ${ }^{68}$ Article 7 of the Treaty contains detailed provisions concerning freedom of navigation and over flight in the Torres Strait region and measures to be taken by Australia and PNG in this context.

\section{J. Settlement of Disputes and Consultation}

Article 29 of the Torres Strait Treaty provides that any dispute arising out of the interpretation or implementation of the Treaty shall be settled by consultation or negotiation. Article 30 of the Treaty obliges Australia and PNG to consult with each other, at the request of either State, on any matters relating to the Treaty.

\section{IMPLEMENTATION OF THE TORRES STRAIT TREATY}

Despite being concluded in 1978, the Torres Strait Treaty did not enter into force until February 1985 upon exchange of instruments of ratification by Australia and PNG ${ }^{69}$ Final ratification of the Treaty was delayed until Australia and PNG could enact the required and complicated 
implementing legislation at multiple levels of government. ${ }^{70}$ In the years following its signature the Torres Strait Treaty continued to receive firm support in Australia and PNG. Neither State appears to have seriously considered withholding ratification. ${ }^{71}$

In the two-and-a-half decades following its entry into force, the Torres Strait Treaty has continued to operate as the primary legal basis for close co-operation between Australia and PNG concerning management of the Torres Strait. Several aspects of the Treaty's co-operative mechanisms have been modified. The Advisory Council, established in accordance with Article 19 of the Treaty, has been supplemented by regular meetings between traditional inhabitants of the Torres Strait region ${ }^{72}$ and regular meetings between government agencies involved in the Treaty's implementation. ${ }^{73}$

The initial ten year term of the Protected Zone seabed mining and drilling moratorium expired in 1995. The moratorium was extended on three occasions between 1995 and 2008. ${ }^{74}$ In 2008 Australia and PNG agreed to extend the moratorium indefinitely. ${ }^{75}$

\section{A MODEL FOR COOPERATIVE MANAGEMENT OF THE SOUTH CHINA SEA?}

There are obvious parallels between the South China Sea and the Torres Strait. Both regions are subject to a tropical climate and exhibit a high degree of biodiversity. ${ }^{76}$ The Torres Strait and South China Sea also contain complex coastal geography, being littered with a wide variety of islands, sand cays and drying reefs. ${ }^{77}$ Apart from these general

70 Charney and Alexander, supra note 32, at 929.

71 Kaye, supra note 2, at 92.

72 See Australian Department of Foreign Affairs and Trade, Torres Strait Treaty and You, online: www.dfat.gov.au/geo/torres_strait/index.htm. These are referred to as Traditional Inhabitants' Meetings.

73 Ibid. These are referred to as Treaty Liaison Meetings.

74 Australian Minister for Foreign Affairs and Trade, Press Release, 'Extension of the Torres Strait Mining Moratorium' (12 February 2008), online: www.foreignminister.gov.au/releases/2008/fa-s033_08.html.

75 Ibid.

76 Concerning biodiversity of the South China Sea, see Y Song, 'A Marine Biodiversity Project in the South China Sea: Joint Efforts Made in the SCS Workshop Process', (2011) 26 Int'1 J Mar \& Coast L 119.

77 Concerning insular features in the South China Sea, see, e.g.: R Smith, 'Maritime Delimitation in the South China Sea: Potentiality and Challenges', (2010) 41 Ocean Dev \& Int'l L 214. 
characteristics of physical geography the two regions have little in common. Key differences will be discussed in the following paragraphs.

\section{A. Economic and Strategic Significance}

In sharp contrast to the Torres Strait region, the South China Sea is proximate to and surrounded by major population centres of the AsiaPacific region. In absolute terms and for the surrounding coastal States, the economic and strategic significance of the South China Sea is not comparable to that of the Torres Strait. For example, fishing activities in the South China Sea produce approximately 10 per cent of the global catch, ${ }^{78}$ which represents the fourth largest regional catch of the world's 19 major fishing regions. ${ }^{79}$ South China Sea fisheries are a key source of livelihood for millions of people living in the region. ${ }^{80}$ The South China Sea also contains some of the world's most important shipping lanes, which run both north-south between the Straits of Malacca and the East China Sea, and east-west from East Asia to Californian ports and the Panama Canal. ${ }^{81}$ These shipping lanes are critical supply routes for oil imported by Japan, the People's Republic of China (PRC), the Republic of China/Taiwan (Taiwan) and the Republic of Korea. ${ }^{82}$ There is persistent speculation that the South China Sea contains large untapped offshore hydrocarbon reserves, although recent research suggests that even on

78 C Schofield, 'Dangerous Ground: A Geopolitical Overview of the South China Sea' in S Bateman and R Emmers, Security and International Politics in the South China Sea: Towards a Cooperative Management Regime (Oxford/New York: Routledge, 2009), at 14-18.

79 United Nations Environment Programme (UNEP), Global International Waters Assessment: South China Sea: Regional Assessment 54 (2005), at 40-1, online: http://www.unep.org/dewa/giwa/areas/reports/r54/giwa_regional_assess ment_54.pdf.

80 C Rahman and M Tsamenyi, 'A Strategic Perspective on Security and Naval Issues in the South China Sea', (2010) 41 Ocean Dev \& Int'1 L 315.

81 See (United Kingdom) Admiralty, Ocean Passages for the World, 5th edn (United Kingdom Hydrographic Office, 2004), at 240-3, cited in Rahman and Tsamenyi, ibid. A commonly cited statistic is that vessel traffic across the South China Sea involves, on an annual basis, approximately half of the global merchant fleet tonnage: Rahman and Tsamenyi, ibid.

82 Japan, South Korea and Taiwan each import more than $80 \%$ of their crude oil via the South China Sea. Between $80-90 \%$ of oil imported by China (which imports over $50 \%$ of its total oil consumption) transits the South China Sea: Rahman and Tsamenyi, supra note 80 . 
optimistic estimates, these reserves would make a marginal contribution to the energy needs of the surrounding States. ${ }^{83}$

\section{B. Importance of Insular Features for Human Settlement}

As noted above, an overarching objective of the Torres Strait Treaty is to protect the life and livelihood of traditional inhabitants of the islands in the Torres Strait. Although several insular features in the South China Sea are inhabited, for the vast majority of features human habitation is dependent on food and water transported from elsewhere ${ }^{84}$ Accordingly, the interests of a culturally and linguistically distinct indigenous island population are not central to management of the South China Sea.

\section{Complexity of Territorial and Jurisdictional Disputes}

Prior to conclusion of the Torres Strait Treaty, competing positions concerning territorial sovereignty and maritime jurisdiction were asserted on a bilateral basis by a developed country (Australia) and a relatively smaller developing former dependent territory (PNG) who shared a common legal heritage and a close co-operative relationship. In contrast, the South China Sea is subject to a complex patchwork of overlapping claims to maritime zones of national jurisdiction asserted by Brunei, Indonesia, Malaysia, the Philippines, PRC, Taiwan and Viet Nam. ${ }^{85}$ Further, all

83 Nick Owen, 'The Value of South China Sea Hydrocarbon Resources' (paper presented at Workshop concerning Maritime Energy Resources in Asia and Opportunities for Joint Development, Ho Chi Minh City, 5-7 August 2010) (unpublished), which finds the following: Optimistic forecasted production rates from undeveloped reserves in the South China Sea will not offset demand for imported oil. Rather, increasing consumption and falling productivity from existing fields is projected to far exceed the estimated production capacity of undeveloped reserves. With the exception of Brunei, all countries bordering the South China Sea are projected to become net importers of crude oil before 2015.

84 Only a few insular features have surface fresh-water and around 13 islands have terrestrial vegetation that indicates a significant degree of soil formation: J.W. McManus et al, 'Toward Establishing a Spratly Islands International Marine Peace Park: Ecological Importance and Supportive Collaborative Activities with an Emphasis on the Role of Taiwan', (2010) 41 Ocean Dev \& Int'l L 270. The largest island in the Spratly archipelago - Itu Aba (or Tai-Ping) is only approximately 1.4 kilometres long and 400 metres wide. The second largest island in the Spratly archipelago - Thitu Island (or Zhongye Dao) has an area of only 0.27 square kilometres. See: Smith, supra note 77.

85 For further discussion see Chapter 2 in this volume, 'International Law, UNCLOS and the South China Sea' by Robert Beckman. 
of these claimants, bar Indonesia, assert competing claims to territorial sovereignty over some or all of the insular features located in the South China Sea. ${ }^{86}$

\section{Political and Military Tensions}

Australia and PNG have a long history of peaceful and co-operative relations and shared priorities concerning the modalities of co-operative management in the Torres Strait. In the decades following World War II the Torres Strait region has been of limited military significance and no military tensions exist between Australia and PNG. ${ }^{87}$ In contrast, relations between several of the South China Sea claimants are associated with a high degree of political and military tension. The competing territorial and jurisdictional claims asserted in the South China Sea are closely intertwined with strong nationalist political sentiment and key strategic interests of the relevant claimants. Given the salient differences discussed above, the design features of the Torres Strait Treaty, which will be discussed in the following paragraphs, are likely to be of limited use for addressing the competing positions advanced by South China Sea claimants.

\section{E. Explicit Recognition of Sovereignty}

As noted above, the Torres Strait Treaty clearly and explicitly recognises the sovereignty of Australia or PNG over certain insular features. It is difficult to imagine the application of equivalent provisions in a South China Sea context, at least in the medium term. The South China Sea claimants exhibit a high degree of sensitivity concerning sovereignty and jurisdictional disputes and are reluctant to act in a manner that may be perceived as detracting from their own claims. ${ }^{88}$ Efforts by the relevant governments to acknowledge or seek a compromise concerning competing claims in the South China Sea are readily misconstrued during national

\footnotetext{
86 Robert Beckman, ibid.

87 See Kaye, supra note 2, at 16-17, who also notes that it is difficult to place mines or operate large naval vessels in the Torres Strait.

88 For example, scholars have noted that, from the perspective of the PRC, recognition by the other claimants of their sovereignty and jurisdiction in the South China Sea is a precondition for discussions the Sea's co-operative management: Peter Kien-hong Yu, 'Setting Up International (Adversary) Regimes in the South China Sea: Analyzing the Obstacles from a Chinese Perspective', (2007) 38 Ocean Dev \& Int'1 L 147.
} 
political debate as an inexcusable 'sell-out' of national interests. Further, allocation of any sovereignty to Taiwan would be politically impossible given the current diplomatic position of PRC concerning the status of the island and its government. Perhaps a better model for the South China Sea would be to develop measures that (1) do not mention sovereignty and jurisdictional issues at all, or (2) apply without prejudice to existing claims. Alternatively, co-operative measures could acknowledge a singular bearer of sovereignty and jurisdiction in a defined area, without specifying the identity of that State. ${ }^{89}$

\section{F. Formal and Close Cooperation at Multiple Levels of Government}

The Torres Strait Treaty also provides in formal terms for close cooperation between Australia and PNG in multiple functional contexts. Successful implementation of the Treaty depended upon implementation of complex legislation at multiple levels of government in Australia and PNG. Negotiation and implementation of the Treaty required sustained political will in both States over a period of several years. Given current political tensions in the South China Sea region and the diverse political and legal systems of the relevant claimants, the prospects of success for an equivalent implementation process would appear to be limited. Perhaps a better model for the South China Sea would be the further development of informal co-operative mechanisms, including: (1) communication channels between national authorities, (2) coordinated implementation and enforcement of existing national laws, and (3) coordinated development of complementary national laws and policy.

\section{G. Emphasis on Protection and Conservation}

The Torres Strait Treaty places a strong emphasis on environmental protection and resource conservation. It affords clear priority to traditional (as opposed to commercial) fishing activities and establishes a moratorium concerning hydrocarbon development. These design features are not appropriate for a South China Sea context, given the high degree of existing economic activity in the region and the dependence of surrounding States on such activity.

89 The latter suggested model is analogous to the basis on which negotiations have proceeded recently between PRC and Taiwan. 


\section{H. No Provision for Military Relations}

The Torres Strait Treaty is not designed to reduce military tensions or strategic competition between its parties and does not contain provisions addressing these matters. Reduction of military tensions and strategic competition in the South China Sea is integral to co-operative management of the region.

Although the above aspects of the Torres Strait Treaty have limited utility given the present status of relations between the South China Sea claimants, the Treaty does contain several innovative design features that may serve as useful models for them to consider, as will be discussed in the following paragraphs.

\section{De-coupling of Maritime Jurisdiction and Territorial Sovereignty}

As noted above, certain Australian islands in the Torres Strait have no effect on the course of the maritime boundaries established by the Torres Strait Treaty. Indeed, several Australian islands are surrounded by waters subject to the jurisdiction of PNG. The de-coupling of maritime jurisdiction and territorial sovereignty enabled negotiators of the Torres Strait Treaty to simultaneously address Australia's desire to retain sovereignty over Torres Strait islands, and PNG's desire to gain greater control over the Strait's resources. The application of a similar approach in the South China Sea could facilitate exchange between claimants of strategic control over disputed insular features in return for authority over the surrounding waters and their resources.

\section{J. De-coupling of Seabed and Water-Column Jurisdiction}

The separate course of the Seabed Jurisdiction Line and Fisheries Jurisdiction Line defined in the Torres Strait Treaty enabled Australia to guarantee the ability of Torres Strait Islanders to access fisheries resources in the central Torres Strait without compromising PNG's access to potential seabed resources in that region. ${ }^{90}$ The application of a similar approach in the South China Sea could facilitate exchange between the

90 See Kaye, supra note 2, at 95. Note however that there are several legal uncertainties associated with the allocation of superimposed maritime jurisdiction to different coastal States - for further discussion see Max Herriman and Martin Tsamenyi, 'The 1997 Australia-Indonesia Maritime Boundary Treaty: A Secure Legal Regime for Offshore Resource Development?', (1998) 29 Ocean Dev \& Int'1 L 361 . 
claimants of control over hydrocarbon resources in return for greater access to marine living resources of the region.

\section{K. De-coupling of Resource Management and Jurisdictional Boundaries}

Fisheries resources within the Torres Strait Protected Zone are managed on a zonal basis by Australia and PNG, reflecting the intention of Australia and PNG to 'ignore the jurisdictional delimitation provisions within the Protected Zone and to manage it as an entity'. ${ }^{11}$ In a South China Sea context the application of a similar zonal management mechanism could provide a basis for the claimants to access a mutually acceptable share of marine resources, notwithstanding the underlying jurisdictional characteristics of the zone. Alternatively, this mechanism could enable South China Sea claimants to exchange underlying maritime jurisdiction in a defined zone in return for a greater share of the zone's resources.

\section{Functionally Comprehensive Management}

A noteworthy feature of the Torres Strait Treaty is the specific provisions concerning all functional aspects of coastal State jurisdiction, including those relating to preservation of the marine environment, marine scientific research and the production of energy from water currents and winds. Much of the current discussion concerning co-operative management of the South China Sea focuses on specific resources, in particular fisheries and offshore hydrocarbon deposits. The Torres Strait Treaty provides a model for managing these resources without overlooking other important functional rights and responsibilities of the relevant coastal States.

\section{Commercial Fisheries Management}

Putting the prioritisation of traditional fishing to one side, the detailed and flexible provisions in the Torres Strait Treaty concerning commercial fisheries management may provide a useful model for co-operative management of marine living resources in the South China Sea.

\section{N. Accounting for Complex and Dynamic Physical Geography}

The measures set out in Articles 2 and 3 of the Torres Strait Treaty (discussed above) are designed to prevent the delicate compromise reflected in

\footnotetext{
91 Burmester, supra note 20.
} 
the Treaty from being undermined by subsequent changes to the physical geography of the Torres Strait. They provide a useful model for avoiding unintended jurisdictional consequences associated with the disappearance of insular features, the formation of new insular features, and other coastline changes. Such provisions are particularly important given the predicted rise of global sea levels. 